\title{
Pengujian Heuristic Pada Antarmuka Marketplace Desa Wisata (Studi Kasus: Guidehub.Id)
}

\author{
Eli Pujastuti ${ }^{1 *}$, Agus Fatkhurohman 2** \\ * Fakultas Ilmu Komputer, Universitas Amikom Yogyakarta \\ eli@amikom.ac.id ${ }^{1}$, agusfatkhurohman@amikom.ac.id $^{2}$
}

\begin{tabular}{l} 
Article Info \\
\hline Article history: \\
Received ... \\
Revised ... \\
Accepted ... \\
\hline
\end{tabular}

Keyword:

Heuristic,

Usability,

Marketplace desa wisata,

8 golden rule.

\begin{abstract}
Ada 229 desa wisata yang saat ini sudah terbentuk di Yogyakarta. Desa wisata tersebut memiliki permasalahan yang beragam, salah satunya adalah pendapatan warga lokal yang tidak meningkat dikarenakan keterbatasan warga dalam mempromosikan desa wisatanya. Platform guidehub.id adalah startup yang membantu desa wisata mempromosikan paket wisata yang dimiliki. Pengguna guidehub.id adalah warga desa wisata. Keragaman latar belakang dari pengguna menuntut pembuatan antarmuka yang mudah digunakan. Kesalahan perancangan antarmuka akan berakibat pada pendapatan desa, Oleh karena itu, sebelum website digunakan oleh pengelola desa wisata, perlu adanya evaluasi terhadap website guidehub.id. Penelitian ini bermaksud mengevaluasi dengan cara mencari nilai severity rate untuk selanjutnya memberikan rekomendasi kepada pengembang website dengan metode usability heuristic. Metode yang digunakan untuk mengukur usability website adalah 8 Golden Rule dari Shneiderman. Hasilnya perbaikan antarmuka marketplace desa wisata (guidehub.id) cukup mayor. Terdapat 5 variabel yang memiliki severity rate tinggi yang artinya harus diperbaiki sebelum website diluncurkan yaitu pada variabel Strive for consistency, Offer informative feedback, Prevent Errors, Permit easy reversal of action dan Support internal locus of control. Rekomendasi untuk temuan yang ada adalah bahasa yang harus konsisten, perlu adanya pemberitahuan apakah user berhasil atau gagal login, sebaiknya ada penanganan error pada saat booking dan submit tour, sebaiknya data tetap ada ketika mengisi form dan ingin kembali ke halaman sebelumnya, dan seharusnya user memiliki control sepenuhnya ketika memilih menghapus tour namun mengurungkan niat untuk menghapus.
\end{abstract}

This is an open access article under the $\mathrm{CC}-\mathrm{BY}-\mathrm{SA}$ license

\section{Pendahuluan}

Peningkatan kunjungan wisatawan menjadi salah satu cara meningkatkan PDB Indonesia. Pariwisata Indonesia berkontribusi pada PDB Indonesia yaitu sebesar 5,25\% [1]. Pariwisata menjadi sektor penting dalam kemajuan Indonesia. Pemerintah melalui program desa wisata telah mendukung desa-desa potensial untuk menjadi desa wisata. Pada 2019 Ada 229 desa wisata yang saat ini sudah terbentuk di Yogyakarta [2]. Desa wisata tersebut memiliki permasalahan yang beragam, salah satunya adalah pendapatan warga lokal yang tidak meningkat dikarenakan keterbatasan warga dalam mempromosikan desa wisatanya [3] dan dari segi wisatawan yang ingin berkunjung ke desa wisata, mereka mengeluhkan minimnya informasi tentang desa wisata. Informasi yang ada saat ini terpisah-pisah pada website, Instagram, dan Blog sehingga wisatawan kesulitan dalam membandingkan harga dan review.

Guidehub.id menawarkan solusi untuk masalah tersebut dengan menjadi media promosi yang terpercaya. Guidehub.id adalah marketplace yang menyatukan informasi desa wisata dalam satu wadah sehingga wisatawan dapat dengan mudah memilih wisata alternatif yang mereka inginkan. Website guidehub.id akan digunakan oleh masyarakat desa wisata dan wisatawan yang akan berkunjung ke desa wisata. Website guidehub.id memiliki fitur login, smart search, booking tour, 
membuat tour, menambahkan guide, wallet, dan konsultasi tour. Dalam penelitian ini, peneliti hanya berfokus pada pengujian dari fitur login, search, membuat tour, dan melakukan booking.

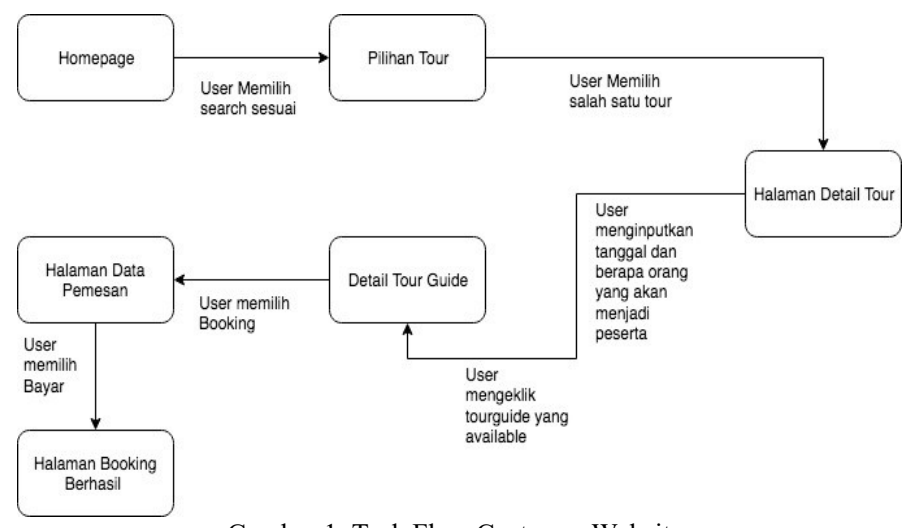

Gambar 1. Task Flow Customer Website

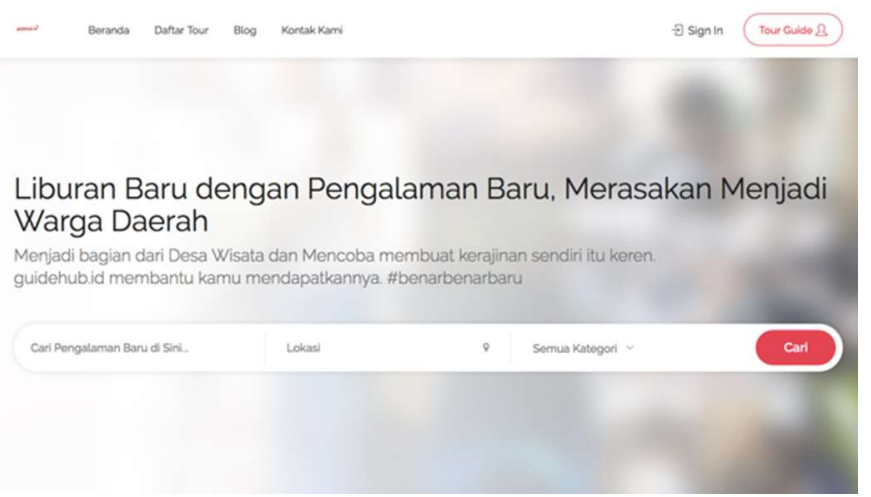

TOUR LIST

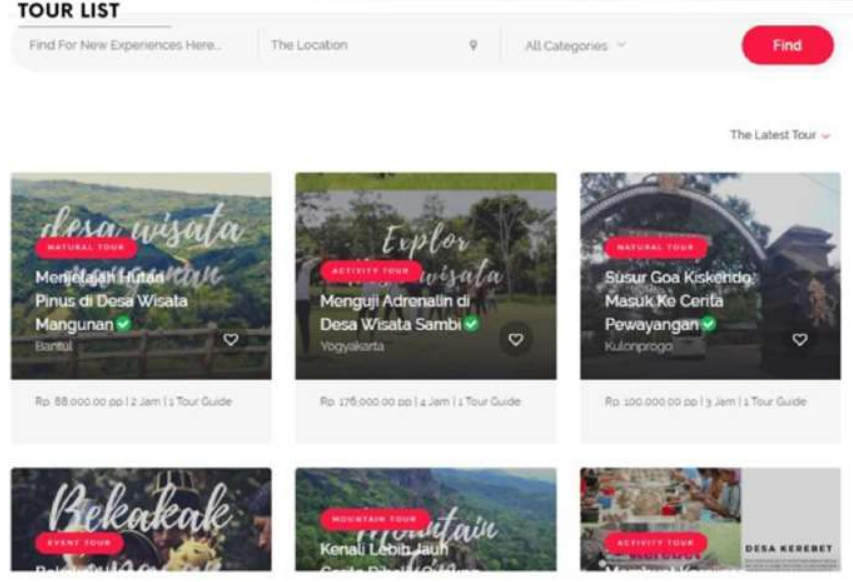

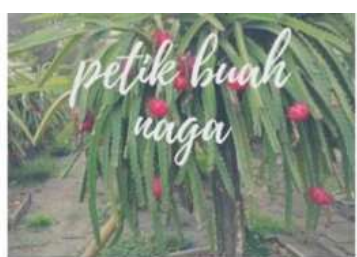
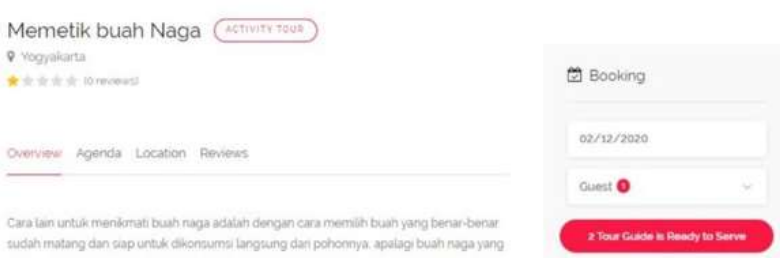

Gambar 2. Tampilan Website Guidehub.id (2019)

Website guidehub.id tersebut akan digunakan oleh pengelola wisata daerah. Keragaman latar belakang dari pengguna menuntut pembuatan antarmuka yang mudah digunakan. Kesalahan perancangan antarmuka akan berakibat pada pendapatan desa. Oleh karena itu, perlu diadakan pengujian sebelum website benar-benar digunakan oleh pengelola wisata daerah. Kesalahan perancangan antarmuka dapat diminimalisir dengan mengadakan pengujian heuristic. Pengujian heuristic bisa menjadi pengujian paling baik untuk mengidentifikasi masalah potensial [4] Pengujian Heuristic akan melibatkan pakar UI/UX untuk memberi masukan perbaikan dari antarmuka marketplace desa wisata. Prinsip yang digunakan dalam penelitian ini adalah prinsip pengujian yang dikemukakan oleh Shneiderman dalam "8 Golden Rule". Rumusan masalah dalam penelitian ini adalah rekomendasi apa yang diberikan untuk perbaikan antarmuka marketplace desa wisata.

Penelitian mengenai pengujian heuristic pernah dilakukan oleh Farida LD yang mengukur usability dengan metode heuristik pada website pariwisata menggunakan teori nielsen, dari hasil penelitian Farida mendapati adanya fitur bantuan dan dokumentasi, standard dan konsistensi, dan kendali dan kebebasan pengguna memiliki severity rating yang lebih tinggi [5]. Penelitian lain juga dilakukan oleh Islam $\mathrm{K}$ dan Agushinta D, mengenai antarmuka Tokopedia. Metode yang digunakan adalah metode heuristic yang dikemukakan oleh Nielsen. Hasilnya ada permasalahan pada 3 aspek usability heuristic yang ditemukan dan menjadi dasar rekomendasi [6]. Penelitian selanjutnya adalah penelitian yang dilakukan oleh Freddy Paz et al, mengenai pengujian heuristik sebagai pelengkap dalam pengujian usability. Penelitian Paz memberi hasil bahwa temuan yang ada dari usability testing biasanya sama dengan yang ditemukan oleh pakar pada pengujian heuristic [7]. Hasil dari penelitian Paz tersebut memberi penekanan bahwa pengujian heuristik penting dilaksanakan, sama seperti usability testing.

Penelitian "Pengujian Heuristic pada Antarmuka Marketplace Desa Wisata" ini mengacu pada teori yang dikemukakan oleh Shneiderman et al pada buku berjudul Designing The User Interface. Shneiderman memberikan 8 
aturan agar antarmuka dapat mendukung usability. Aturan tersebut diberi nama "Golden Rule". Aturan yang disempurnakan selama 3 dekade [8]. Pengujian heuristic adalah pengujian yang efektif dan lebih cepat. Jakob Nielsen merekomendasikan 3 sampai dengan 5 evaluator saja yang terlibat [9].

\section{Metode Penelitian}

\section{A. Metode Penelitian}

Metode pengujian heuristic dalam penelitian ini adalah dengan menganalisis dan merumuskan masalah, mencari literature yang terkait dengan metode yang dapat digunakan sebagai referensi, mengumpulkan data dari evaluator, menganalisis data, dan menentukan temuan dan rekomendasi.

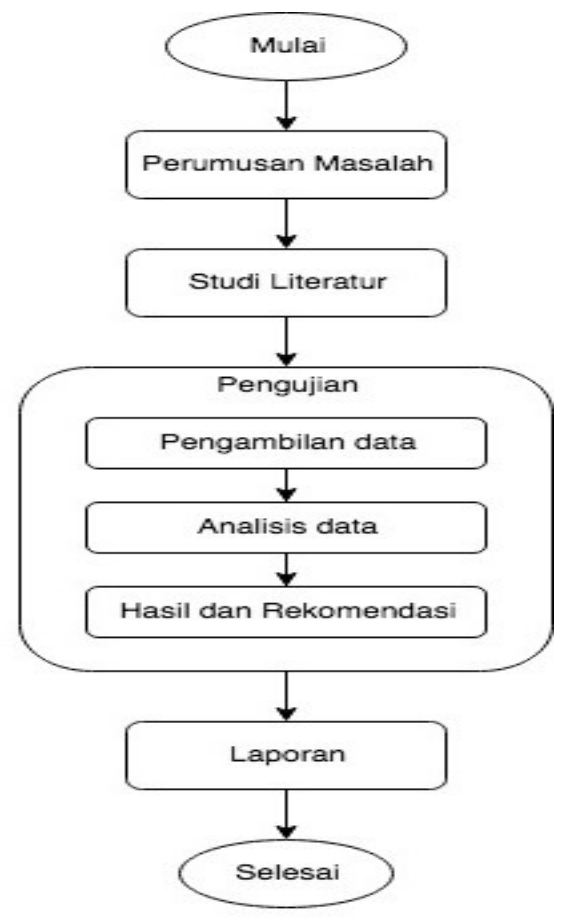

Gambar 3. Bagan Alir Penelitian

\section{B. Metode Pengumpulan Data}

Data yang diambil pada penelitian ini adalah data kualitatif dan kuantitatif dari para ahli. Ahli yang menjadi evaluator adalah 3 orang. Pada penelitian kualitatif banyaknya objek lebih sedikit dibandingkan penelitian kuantitatif karena lebih mengedepankan kedalaman data, bukan kuantitas data [10]. Data kualitatif didapatkan dari pendapat dari ahli saat pengujian. Data kuantitatif didapatkan dari hasil severity rate.

Evaluator menguji tanpa tugas khusus yang diberikan oleh observer. Evaluator mensimulasikan diri menjadi turis yang ingin menggunakan platform guidehub.id dan menjadi pengelola desa wisata yang merupakan pemandu wisata yang akan membuat paket wisata pada platform. Evaluator berjumlah tiga orang telah dipilih dengan detail sebagai berikut:

TABEL I.

DAFTAR EVALUATOR

\begin{tabular}{|l|l|l|}
\hline No & Nama & Keahlian \\
\hline 1 & $\begin{array}{l}\text { Arvin Claudy F. } \\
\text {,M.Kom }\end{array}$ & Akademisi bidang UI/UX \\
\hline 2 & $\begin{array}{l}\text { Rifda Faticha Alfa } \\
\text { Aziza,M.Kom }\end{array}$ & $\begin{array}{l}\text { Senior UI/UX Designer dan } \\
\text { Akademisi bidang Interaksi } \\
\text { Manusia dan Komputer }\end{array}$ \\
\hline 3 & $\begin{array}{l}\text { Rakhma Shafrida } \\
\text { Kurnia, M.Kom }\end{array}$ & $\begin{array}{l}\text { Akademisi di bidang } \\
\text { Interaksi Manusia dan } \\
\text { Komputer }\end{array}$ \\
\hline
\end{tabular}

Evaluator dengan pengalaman sedikit lebih bagus menggunakan checklist [12]. Evaluator pada penelitian ini merupakan expert yang sudah memiliki pengalaman di bidang usability lebih dari 3 tahun, maka tidak diperlukan checklist.

Waktu pengujian tidak bersamaan, evaluator memberikan pendapat dan masukan pada observer, lalu observer mendokumentasikan kedalam sebuah form bersama dengan severity rate yang ditentukan oleh evaluator di setiap aspek penilaian. Severity rate adalah tujuan kedua dari pengujian heuristic setelah menemukan semua masalah usability, lalu mengukur tingkat keparahan masalah tersebut [13].

\section{Metode Analisis}

Pada tahap pengujian, penelitian ini menggunakan 8 Golden Rule dari Shneiderman [8] dimana pengujian dapat dikategorikan menjadi berikut:

1) Strive for consistency

Variabel ini menilai hal-hal yang identik yang biasa digunakan pada prompt, menu, dan layar bantuan, warna, tata letak, huruf besar, dan font yang konsisten.

2) Seek universal usability

Adanya fitur untuk pemula seperti penjelasan dan fitur untuk para ahli seperti pintasan dan langkah lebih cepat.

3) Offer informative feedback

Variabel ini merupakan umpan balik (feedback) dari setiap action yang dilakukkan oleh pengguna pada antarmuka. Tindakan yang sering dan kecil responnya bisa sederhana, sedangkan untuk tindakan yang jarang dan besar.

4) Design dialogue to yield closure

Tindakan pengguna terhadap system dikelompokkan dalam kelompok awal, tengah, dan akhir. Pengguna membutuhkan umpan balik yang informatif pada setiap penyelesaian sekelompok tindakan. Umpan balik tersebut memberi pengguna kepuasan atas pencapaian, rasa lega dan indikator untuk mempersiapkan kelompok tindakan selanjutnya.

5) Prevent Errors 
Pada variabel ini membahas mengenai desain antarmuka yang dapat mencegah agar pengguna tidak melakukan kesalahan serius. Tetapi jika pengguna membuat kesalahan, harus ada antarmuka yang memberi penawaran kepada pengguna berupa pesan/instruksi sederhana, konstruktif, dan spesifik untuk menyelesaikan kesalahan tersebut.

6) Permit easy reversal of action

Pada variabel ini antarmuka haruslah memiliki fitur untuk mengembalikan pada tindakan sebelumnya. Fitur ini mengurangi kecemasan karena pengguna tahu bahwa kesalahan dapat diurungkan.

7) Support internal locus of control Variabel ini memungkinkan pengguna yang berpengalaman menginginkan perasaan bahwa mereka bertanggung jawab atas antarmuka dan antarmuka merespon tindakan mereka.

8) Reduce short-term memory load

Variabel ini berhubungan dengan kapasitas manusia yang terbatas untuk pemrosesan informasi dalam memori jangka pendek (aturan praktisnya adalah bahwa orang dapat mengingat "tujuh plus atau minus dua potongan" informasi). Hal ini mengharuskan perancang antarmuka untuk tidak memaksa pengguna mengingat terlalu banyak informasi pada satu halaman dan menggunakan informasi tersebut pada halaman berikutnya.

Metode evaluasi heuristic banyak dipakai karena tidak membutuhkan banyak biaya (efisien) dan lebih mudah diaplikasikan [14][15][16][17]. Metode selain 8 Golden Rule Shneiderman, seperti Ten Usability Heuristic terlalu general untuk mengevaluasi website [18].

TABEL II.

PENAmaAn VARiabel Penilaian

\begin{tabular}{|l|c|}
\hline Variabel Penilaian & Variabel \\
\hline Strive for consistency & A1 \\
\hline Seek universal usability & A2 \\
\hline Offer informative feedback & A3 \\
\hline Design dialogue to yield closure & A4 \\
\hline Prevent Errors & A5 \\
\hline Permit easy reversal of action & A6 \\
\hline Support internal locus of control & A7 \\
\hline Reduce short-term memory load & A8 \\
\hline
\end{tabular}

Setelah evaluator menyampaikan evaluasi, evaluator akan memberikan penilaian berupa angka severity. Severity dapat diukur dengan nilai atara 0-4, tergantung seberapa besar dampak yang ditimbulkan.

Ketentuan nilai severity rate adalah sebagai berikut [11]:

$0=$ Sama sekali bukan masalah usability

$1=$ Cosmetic problem only (tidak perlu diperbaiki

kecuali ada waktu lebih yang memungkinkan)

2 = Minor usability problem (prioritas rendah)
3 = Major usability problem (penting untuk diperbaiki, prioritas tinggi)

4 = Usability Catastrophe (harus diperbaiki sebelum produk rilis)

\section{Hasil Penelitian}

Pengambilan data dimulai dengan menghadirkan expert atau ahli UI/UX untuk menjadi evaluator. Website guidehub.id sudah bisa diakses secara online, namun belum secara resmi diluncurkan. Sebelum diluncurkannya website tersebut, dilakukan pengujian heuristic terlebih dahulu untuk mengurangi risiko turis yang kecewa karena tidak bisa menggunakan website dan mitra desa wisata yang tidak ingin menggunakan lagi dikarenakan error yang seringkali muncul. Masing-masing evaluator menggunakan kata-kata yang tidak sama untuk mendeskripsikan masalah yang sama. Variabel A1 mendapat penilaian sebagai berikut:

- E1 menemukan adanya ketidakkonsistensian dalam pemilihan warna tombol login tour guide dengan tombol-tombol yang lain.

- E2 menilai bahwa terdapat masalah konsistensi pada Bahasa yang digunakan sebagian besar menggunakan Bahasa Indonesia namun pada sisi lain seperti di kategori wisata, menggunakan bahasa inggris. Hal lain yang membuat web tidak konsisten adalah ketika user mencoba scroll down pada menu review secara tiba-tiba scroll up tanpa perintah user.

- $\quad$ E3 menyoroti pada ketidakkonsistenan card (thumbnail) daftar tour yang menggunakan warna background yang berbeda yaitu putih pada halaman pertama, namun abuabu pada halaman lain dan tidak adanya icon bookmark pada daftar tour, sedangkan di daftar tour popular ada.

Hasil paparan penilain dari para evaluator tersebut mengakibatkan masing-masing evaluator memberikan nilai 4 pada variabel A1.

Variabel A2 mendapatkan penilaian sebagai berikut:

- E1 dan E3 menemui masalah pada saat user mencoba mencari tour padahal user yang sama sudah pernah mencari tour tertentu, website tidak memberikan recent search.

- $\quad$ E2 memberikan pandangan yang berbeda pada sisi login turis dan login tour guide yang sebaiknya dibuat terpisah. Selain itu, E2 menilai icon media social yang tidak berfungsi dan dropdown pilihan Bahasa yang secara hierarchy tidak tepat berada sejajar dengan menu lain.

Paparan penilaian tersebut menyebabkan variabel A2 mendapat nilai bervariasi sehingga memiliki rata-rata sebesar 3,33. Variabel A3 memiliki penilaian dari semua evaluator, yaitu:

- E1 menyampaikan pendapatnya bahwa tidak ada notifikasi saat user berhasil atau gagal pada saat mendaftar, begitu pula untuk pengguna yang merupakan tour guide tidak ada pemberitahuan ketika tour guide membuat tour baru berhasil atau tidaknya. 
- $\quad$ E2 masalah muncul field password yang tidak diisi, lalu user memilih untuk login dalam keadaan password kosong, system tidak memberi peringatan apapun

- E3 menemukan adanya masalah yaitu tidak adanya pemberitahuan kepada user ketika user membuat tour baru.

Penilaian pada variabel A3 tersebut mengakibatkan penilaian pada aspek A3 mendapat nilai 4. Variabel A4 mendapat nilai yang sama pada E1 dan E3, sedangkan E2 memberikan nilai 1 dengan rincian sebagai berikut:

- E1 dan E3 berpendapat masalah berada pada pengisian form, karena form tidak bersinar yang menunjukkan bahwa kursor sedang ada pada form tersebut. Ketika user ingin mengisi form, user tidak mengetahui dimana letak kursornya, dikarenakan textfield pada form tidak memberi warna yang bersinar di sekeliling textfield

- E2 Menilai bahwa user masih menerka-nerka apakah booking yang mereka lakukan sudah berhasil atau belum dikarenakan tidak adanya notifikasi ketika tombol booking di klik.

Penilaian dari para evaluator pada variabel A4 mengakibatkan nilai rata-rata severity yang didapatkan adalah 1,66. Variabel A5 mendapatkan penilaian berupa:

- E1 berpendapat masalah berada pada saat tour guide membuat wisata baru, tour guide akan kesulitan mengisikan agenda, gambar yang akan dicantumkan harus berukuran kecil tetapi tidak ada pemberitahuan mengenai ketentuan tersebut. Placeholder pada harga tour tidak hilang padahal textfield sudah diklik.

- $\quad$ E2 memberikan penilaian dari hal yang kurang yaitu ketika turis memilih booking tour dan terjadi error, tidak adanya notifikasi error. Masalah berupa deskripsi agenda waktu start dan berakhirnya, tidak adanya tanggal kapan tour guide available

- $\quad$ E3 menilai ada masalah pada login yang tidak memberi pemberitahuan tentang kesalahan ketika user tidak menginputkan password pada saat login. Begitu pula ketika user menginputkan password yang salah, website tidak memberi tanda error.

Penilaian evaluator tersebut menyebabkan nilai severity sebesar 4 pada masing-masing evaluator. Variabel A6 evaluator menyoroti masalah-masalah berikut:

- E1 menilai adanya masalah ketika mengisi form sebagai tour guide lalu salah mengisikan agenda, user harus mengulang dari awal.

- E2 menilai adanya masalah ketika mengetikkan format yang salah pada form, tidak ada pemberitahuan adanya kesalahan sehingga user baru mengetahui ketika user sudah submit.

- E3 menilai adanya masalah pada saat user tidak bisa kembali ke form yang sebelumnya ketika terjadi kesalahan pengisian form, user harus menginputkan lokasi kembali.

Berdasarkan masalah-masalah tersebut, evaluator memberikan nilai severity 4. Variabel A7 menitikberatkan pada masalah ketika tour guide ingin menghapus tour yang telah mereka buat.

- E1, E2, dan E3 mendapati adanya masalah ketika tour guide ingin menghapus tour, maka tour itu hilang tanpa ada pertanyaan lanjutan kepada tour guide. Pertanyaan lanjutan yang dimaksud adalah seperti "Apakah anda yakin ingin menghapus tour ini?"

Evaluator 1, 2, dan 3 senada dalam evaluasinya dan mengakibatkan nilai rata-rata severity menjadi 4. Variabel A8 mendapat paparan permasalahan sebagai berikut:

- $\quad$ E1 dan E2 tidak ada masalah pada aspek ini

- E3 menemukan masalah pada pencarian, placeholder pada pencarian susah dimengerti

Evaluator 1 dan 2 menyatakan tidak adanya masalah pada aspek ini, Evaluator 3 memberi nilai 1 sehingga rata-rata nilai severity pada A8 adalah nilai 0.33 .

Hasil evaluasi dapat dilihat pada Tabel 3 berikut ini:

TABEL III.

Hasil Penilaian SeVerity Rate dari Semua Evaluator

\begin{tabular}{|c|c|c|c|c|c|}
\hline Variabel & E1 & E2 & E3 & $\begin{array}{c}\text { Rata- } \\
\text { rata }\end{array}$ & $\begin{array}{c}\text { St. } \\
\text { Deviasi }\end{array}$ \\
\hline A1 & 4 & 4 & 4 & 4 & 0.00 \\
\hline A2 & 3 & 4 & 3 & 3.33 & 0.577 \\
\hline A3 & 4 & 4 & 4 & 4 & 0.00 \\
\hline A4 & 2 & 1 & 2 & 1.66 & 0.577 \\
\hline A5 & 4 & 4 & 4 & 4 & 0.00 \\
\hline A6 & 4 & 4 & 4 & 4 & 0.00 \\
\hline A7 & 4 & 4 & 4 & 4 & 0.00 \\
\hline A8 & 0 & 0 & 1 & 0.33 & 0.577 \\
\hline
\end{tabular}

Keterangan Tabel 3:

$\mathrm{E} 1=$ Evaluator 1

$\mathrm{E} 2=$ Evaluator 2

$\mathrm{E} 3=$ Evaluator 3

Pengukuran menggunakan nilai rata-rata yang dianggap mewakili data dikarenakan nilai standard deviasi data masih menunjukkan nilai yang tidak menyebar. Hasil evaluasi menjadi dasar pengambilan rekomendasi untuk perbaikan antarmuka website guidehub.id seperti pada Tabel 4 berikut.

TABEL IV.

REKOMENDASI

\begin{tabular}{|c|c|}
\hline Variabel & \multicolumn{1}{|c|}{ Rekomendasi } \\
\hline A1 & $\bullet \begin{array}{l}\text { Sebaiknya menggunakan Bahasa Indonesia } \\
\text { semua, pada halaman berbahasa Indonesia. }\end{array}$ \\
& $\begin{array}{l}\text { Tetap menggunakan warna background yang } \\
\text { sama yaitu putih. Trik yang digunakan jika }\end{array}$ \\
\hline
\end{tabular}




\begin{tabular}{|c|c|}
\hline & $\begin{array}{l}\text { komponen diatasnya menggunakan warna yang } \\
\text { sama adalah dengan memberi shadow pada tepi } \\
\text { komponen. Warna tombol sebaiknya konsisten. } \\
\text { Scroll down yang sebaiknya sesuai dengan } \\
\text { action yang dilakukan oleh user. } \\
\text { - Icon bookmark yang harus ada pada setiap card. } \\
\text { Harus konsisten, jika di daftar tour populer ada, } \\
\text { maka di halaman lain juga ada. }\end{array}$ \\
\hline A2 & $\begin{array}{l}\text { - Sebaiknya ada recent search yang muncul ketika } \\
\text { user ingin mencari tour } \\
\text { - Peringkasan shortcut untuk login pada satu } \\
\text { tampilan yang sama, baik itu turis maupun tour } \\
\text { guide. Sebaiknya tampilan dibuat dalam satu } \\
\text { halaman yang sama hanya dibedakan dengan } \\
\text { tab. } \\
\text { - Shortcut media social sebaiknya di fungsikan. } \\
\text { Pengguna yang akan membagikan informasi } \\
\text { mengenai tour akan dengan otomatis memilih } \\
\text { icon sosial media, pengguna akan merasa } \\
\text { kecewa jika icon tersebut ternyata tidak } \\
\text { berfungsi. } \\
\text { - Shortcut Bahasa dipindah ke pojok kanan atas. } \\
\text { Shortcut untuk mengganti bahasa berada sejajar } \\
\text { dengan menu, secara hirarki pengguna akan } \\
\text { menganggap bahwa pilihan bahasa adalah menu } \\
\text { yang sama pentingnya dengan menu yang sejajar } \\
\text { dengannya. }\end{array}$ \\
\hline A3 & $\begin{array}{l}\text { - Dibuat pemberitahuan ketika user berhasil atau } \\
\text { gagal mendaftar. } \\
\text { - Perlu ada pemberitahuan jika pembuatan tour } \\
\text { berhasil atau gagal, dengan begitu pengguna } \\
\text { akan berhenti menerka mengenai tindakannya. } \\
\text { - Perlu adanya pemberitahuan bahwa field } \\
\text { password harus diisi sebelum login, akan lebih } \\
\text { bagus jika pengguna diberi tahu dengan tulisan } \\
\text { berwarna merah jika mereka belum mengisi } \\
\text { password saat mencoba login, sebelum isi field } \\
\text { tersebut diolah oleh sistem. }\end{array}$ \\
\hline A4 & $\begin{array}{l}\text { - Ditambahkan adanya warna yang bersinar pada } \\
\text { sekeliling field saat kursor aktif pada field } \\
\text { tersebut. Fitur ini akan membantu pengguna } \\
\text { dalam mencari dimana mereka berada saat itu. } \\
\text { - Tambahkan notifikasi untuk memberi tahu user } \\
\text { bahwa action pada saat user memilih tombol } \\
\text { booking sudah berhasil }\end{array}$ \\
\hline A5 & $\begin{array}{l}\text { - Tambahkan deskripsi agenda waktu start dan } \\
\text { berakhirnya, tambahkan tanggal kapan tour } \\
\text { guide available. Deskripsi ini akan membantu } \\
\text { pengguna mengetahui bagaimana mereka akan } \\
\text { mulai mengisi form. } \\
\text { - Perlu adanya catatan yang memberitahu user } \\
\text { bahwa image yang dapat diupload hanyalah file } \\
\text { berukuran kecil ( }<2 \mathrm{MB}) \text {. Fitur ini akan } \\
\text { mencegah pengguna menunggu terlalu lama } \\
\text { untuk suatu kesalahan. } \\
\text { - Perlu adanya pemberitahuan ketika terjadi error } \\
\text { pada saat booking tour maupun membuat tour } \\
\text { - Perlu ada notifikasi bahwa password harus diisi } \\
\text { dan harus benar, jika salah maka halaman web } \\
\text { tidak akan dilanjutkan }\end{array}$ \\
\hline
\end{tabular}

\begin{tabular}{|c|c|}
\hline A6 & • $\begin{array}{l}\text { Sebaiknya ada notifikasi (berwarna merah) pada } \\
\text { saat mengisikan format yang salah pada data tour } \\
\text { sebelum user memilih tombol submit. } \\
\text { • }\end{array}$ \\
\hline A7 & $\begin{array}{l}\text { Sebaiknya data tetap ada meskipun user salah } \\
\text { memilih tombol submit dan ingin menyuntingnya }\end{array}$ \\
& $\begin{array}{l}\text { Sebaiknya ada warning ketika tour guide ingin } \\
\text { menghapus data tour nya, untuk menghindari } \\
\text { kehilangan data dikarenakan salah memilih menu } \\
\text { hapus tour }\end{array}$ \\
\hline A8 & $\begin{array}{l}\text { Sebaiknya placeholder diganti dengan Bahasa } \\
\text { yang lebih mudah dimengerti seperti: "tour apa } \\
\text { yang anda inginkan?" }\end{array}$ \\
\hline
\end{tabular}

\section{KESIMPULAN}

Perbaikan antarmuka marketplace desa wisata (guidehub.id) cukup mayor. Terdapat 5 variabel yang memiliki severity rate tinggi yang artinya harus diperbaiki sebelum website diluncurkan, semakin tinggi nilai severity, maka semakin menjadi prioritas untuk diperbaiki. Rekomendasi untuk temuan yang ada adalah bahasa yang harus konsisten, perlu adanya pemberitahuan apakah user berhasil atau gagal login, sebaiknya ada penanganan error pada saat booking dan submit tour, sebaiknya data tetap ada ketika mengisi form dan ingin kembali ke halaman sebelumnya, dan seharusnya user memiliki control sepenuhnya ketika user terlanjur memilih hapus tour, maka sebaiknya ada konfirmasi apakah benar-benar ingin dihapus. Saran untuk penelitian berikutnya adalah analisis perbandingan setelah antarmuka diperbaiki.

\section{UCAPAN TERIMA KASIH}

Ucapan terimakasih ditujukan kepada Tim Guidehub.id dan kepada evaluator yang telah meluangkan waktu memberikan masukkan dan pendapat.

\section{DAFTAR PUSTAKA}

[1] BPS, "6 Februari 2019," 2019.

[2] D. Bappeda, "Daerah DIY - Pariwisata," Aplikasi Dataku DIY, 2019. [Online]. Available: http://bappeda.jogjaprov.go.id/dataku/data_dasar/cetak/211pariwisata. [Accessed: 20-Feb-2020].

[3] Kompas.com, "Pengembangan Desa Wisata Terkendala Promosi," 2012. [Online]. Available: https://travel.kompas.com/read/2012/10/14/19571078/Penge mbangan.Desa.Wisata.Terkendala.Promosi. [Accessed: 20Feb-2020].

[4] B. Shneiderman, Research-Based Web Design \& Usability Guidelines. US Department of Health and Human Services (HHS) and the US General Services Administration (GSA). 2013.

[5] L. D. Farida, "Pengukuran User Experience Dengan Pendekatan Usability [Kasus: Website Pariwisata Di Asia Tenggara]," Semin. Nas. Teknol. Inf. dan Multimed., pp. 6-7, 2016.

[6] K. Islam and D. A. Rahayu, "Evaluasi Antarmuka Website Tokopedia menggunakan Metode Heuristic," Electron. J., vol. 8, no. 1, pp. 33-38, 2018.

[7] F. Paz, F. A. Paz, D. Villanueva, and J. A. Pow-Sang, "Heuristic Evaluation as a Complement to Usability Testing: 
A Case Study in WEB Domain," Proc. - 12th Int. Conf. Inf. Technol. New Gener. ITNG 2015, pp. 546-551, 2015.

[8] B. Shneiderman, C. Plaisant, M. Cohen, S. Jacobs, N. Elmqvist, and N. Diakolpoulos, Designing The User Interface, Sixth Edit. Essex, England: Pearson, 2016.

[9] J. Nielsen, "Heuristic Evaluation: How-To: Article by Jakob Nielsen," $1994 . \quad$ [Online]. Available: https://www.nngroup.com/articles/how-to-conduct-aheuristic-evaluation/. [Accessed: 25-Jan-2020].

[10] R. Adi, Metodologi penelitian sosial dan hukum. Penerbit Media Sahabat Cendekia, 2004.

[11] Jakob Nielsen, "Severity Ratings for Usability Problems: Article by Jakob Nielsen," 1994. [Online]. Available: https://www.nngroup.com/articles/how-to-rate-the-severityof-usability-problems/. [Accessed: 18-Feb-2020].

[12] R. Khajouei, S. Hajesmaeel Gohari, and M. Mirzaee, "Comparison of two heuristic evaluation methods for evaluating the usability of health information systems," $J$. Biomed. Inform., vol. 80, no. August 2017, pp. 37-42, 2018.

[13] S. Herr, N. Baumgartner, and T. Gross, "Evaluating severity rating scales for heuristic evaluation," Conf. Hum. Factors Comput. Syst. - Proc., vol. 07-12-May-, pp. 3069-3075, 2016.

[14] B. Landford et al., "Preprint : final version of paper available from Analytical Usability Evaluation for Digital Libraries : a Case Study," 2004.

[15] Z. Tang, T. R. Johnson, R. D. Tindall, and J. Zhang, "Applying heuristic evaluation to improve the usability of a telemedicine system," Telemed. J. e-Health, vol. 12, no. 1, pp. 24-34, 2006.

[16] J. Zhang, T. R. Johnson, V. L. Patel, D. L. Paige, and T. Kubose, "Using usability heuristics to evaluate patient safety of medical devices," J. Biomed. Inform., vol. 36, no. 1-2, pp. 23-30, 2003 .

[17] P. Rezaei-Hachesu, E. Pesianian, and M. Mohammadian, "Evaluating usability of radiology information systems in hospitals of Tabriz University of medical sciences," Acta Inform. Medica, vol. 24, no. 1, pp. 42-46, 2016

[18] C. Jimenez, P. Lozada, and P. Rosas, "Usability heuristics: A systematic review," 2016 IEEE 11th Colomb. Comput. Conf. CCC 2016 - Conf. Proc., pp. 1-8, 2016. 